\title{
LITHUANIAN HISTORICAL
}

\section{STUDIES}

\author{
Vol. 22
}

2018

LITHUANIAN INSTITUTE OF HISTORY FERDINAND SCHÖNINGH 


\section{LITHUANIAN}

\section{HISTORICAL}

\section{STUDIES}

Vol. 22

2018

LITHUANIAN INSTITUTE OF HISTORY FERDINAND SCHÖNINGH

VILNIUS, 2018 


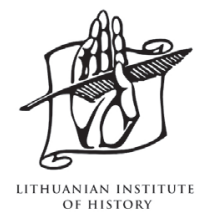

THIS PUBLICATION WAS FUNDED BY A GRANT

(No. LIP-068/2016)

FROM THE RESEARCH COUNCIL OF LITHUANIA

Published by the Lithuanian Institute of History, Vilnius

Articles appearing in this journal are abstracted and indexed in:

HISTORICAL ABSTRACTS

AMERICA: HISTORY AND LIFE

EBSCO PUBLISHING

BRILL

SCOPUS

Bibliografische Information der Deutschen Nationalbibliothek

Die Deutsche Nationalbibliothek verzeichnet diese Publikation in der Deutschen Nationalbibliografie; detaillierte bibliografische Daten sind im Internet über http://dnb.d-nb.de abrufbar.

Alle Rechte vorbehalten. Dieses Werk sowie einzelne Teile desselben sind urheberrechtlich geschützt. Jede Verwertung in anderen als den gesetzlich zugelassenen Fällen ist ohne vorherige schriftliche Zustimmung des Verlags nicht zulässig.

(C) 2018 Verlag Ferdinand Schöningh, ein Imprint der Brill Gruppe (Koninklijke Brill NV, Leiden, Niederlande; Brill USA Inc., Boston MA, USA; Brill Asia Pte Ltd, Singapore; Brill Deutschland $\mathrm{GmbH}$, Paderborn, Deutschland)

(C) Lithuanian Institute of History, 2018

Internet: www.schoeningh.de

Einbandgestaltung: Evelyn Ziegler, München Herstellung: Brill Deutschland GmbH, Paderborn

ISSN 1392-2343 


\section{CONTENTS}

\section{Articles}

\section{Vaida Kamuntavičienè}

The Founding of the Convent of the Congregation of St Catherine in Krakès in the 17th Century ................................. 1

Agnè Railaité-Bardè

The Triumphant Genealogical Awareness of the Nobility in the Grand Duchy of Lithuania in the 17th and 18th Centuries .... 29

Remigijus Civinskas

Amid the Changing Landscape of City, Class and Imperial Russian Policy: The Habitus of the Kaunas Urban Elite and their Symbolic Representation in the Early 19th Century .......... 51

Ugnè Marija Andrijauskaite

Inventing the Communist Party of Lithuania as a Labour Movement. Narratives in Soviet Historiography

Brigita Tranavičiūtè

Soviet Consumer Goods Advertising: Propaganda and Consumption in the 1950s-1980s in Lithuania

Saulius Grybkauskas

The Making of the Titular Nation Engineers in

Soviet Lithuania and Latvia (from the end of the 1940s to the Mid-1950s)

\section{Book Reviews}

Marius Ščavinskas

Darius Baronas, S.C. Rowell, The Conversion of Lithuania.

From Pagan Barbarians to the Late Medieval Christians 161

\section{Darius Baronas}

Paul Srodecki, Antemurale Christianitatis: Zur Genese der Bollwerksrhetorik im östlichen Mitteleuropa an der Schwelle vom Mittelalter zur Frühen Neuzeit 
Marius Ščavinskas

Jiř́i Dynda, Slovanské Pohanství ve středověkých latinských pramenech

Catherine Gibson

Vasilijus Safronovas, The Creation of National Spaces in a Pluricultural Region: The Case of Prussian Lithuania

Jolita Sarcevičienè

Dalia Leinarte, The Lithuanian Family in its European Context, 1800-1914. Marriage, Divorce and Flexible Communities ...... 187

Olga Mastianica-Stankevič

Beata Kalęba, Rozdroże. Literatura polska w kręgu litewskiego

odrodzenia narodowego

Karsten Brüggemann

Tomas Balkelis, Violeta Davoliūtè (eds.), Population Displacement in Lithuania in the Twentieth Century. Experiences, Identities and Legacies 202

Vitalija Stravinskiene

Audrius A. Žulys, Polska w polityce zagranicznej Litwy w latach 1938-1939. Studium z historii dyplomacji 206

Fabio Belafatti

Christine Beresniova, Holocaust Education in Lithuania.

Community, Conflict, and the Making of Civil Society

Una Bergmane

Eglè Rindzevičiūte, The Power of Systems. How Policy Sciences

Opened up the Cold War World

Vasilijus Safronovas

Eva-Clarita Pettai, Vello Pettai, Transitional and Retrospective Justice in the Baltic States 